\title{
EPIDEMIOLOGI KASUS BEDAH PLASTIK DI RSUD SYARIFAH AMBAMI RATO EBHU BANGKALAN, PENELITIAN RETROSPEKTIF DUA TAHUN
}

\author{
Nova Primadina ${ }^{1}$ \\ Medical Faculty of Muhammadiyah Surabaya University, Jawa Timur, Indonesia/ \\ ex-Plastic Surgeon RSUD Syarifah Ambami Rato Ebhu Bangkalan-Madura \\ e-mail: novaprimadina@fk.um-surabaya.ac.id
}

\begin{abstract}
Syarifah Ambami Rato Ebhu Bangkalan Hospital is a referral hospital type B in Madura island, but there has never been a Plastic Surgery specialist services before 2015. This research is done to know the epidemiology of Plastic surgery cases treated at Syarifah Ambami Rato Ebhu Hospital Madura in two years. The study was a descriptive retrospective observational study with a sample of the entire population of outpatient and inpatient handled by Plastic Surgeon in a span of two years. The case of Plastic Surgery Data collected show an increase in patients as much as $34.1 \%$ of 129 patients in 2015 to 173 patients in 2016, the case has risen significantly by 130\% from 23 cases in 2015 to 53 cases in the year 2016, and the non-operative cases increase by 13.2\% from 106 cases to 120 cases with details of the five most cases are handled by a specialist plastic surgery are: chronic wounds with a total of 72 cases has increased $127 \%$ in year 2, wounds fuels with a total of 35 cases has increased $18.75 \%$ in year 2, vulnus appertum as many as 31 cases increased by $38.46 \%$ in the year-to-two years, as many as 25 cases of keloid has increased $50 \%$ in year 2 years, and basalioma with a total of 23 cases, decreased $35.7 \%$ in year 2 years after the holding extension. The case of Plastic Surgery and the number of patients has increased significantly since the holding of Plastic Surgery services in Syarifah Ambami Rato Ebhu Bangkalan hospital. Unfortunately this service is discontinued. Therefore, it should be a Plastic Surgeon specialist service continuously in Bangkalan hospital Madura, supporting Presidential Decree No.04 in 2017 to assist the efficiency and effectiveness of the Maduranese who require specialist services in plastic surgery.
\end{abstract}

Keywords: plastic surgery cases, Bangkalan, Madura, epidemiology

Abstrak: RSUD Bangkalan merupakan rumah sakit tipe B rujukan se-pulau Madura, tetapi belum pernah ada pelayanan spesialis Bedah Plastik sebelum tahun 2015 Penelitian ini dilakukan untuk mengetahui data epidemiologi kasus Bedah Plastik yang di terapi di RSUD Syarifah Ambami Rato Ebhu Bangkalan Madura dalam dua tahun ini. Penelitian ini adalah penelitian deskriptif retrospektif observasional dengan sampel seluruh populasi pasien rawat jalan dan rawat inap yang ditangani oleh Spesialis Bedah Plastik dalam kurun waktu dua tahun. Data kasus Bedah Plastik yang berhasil dikumpulkan menunjukkan peningkatan pasien sebanyak 34,1\% dari 129 pasien di tahun 2015 menjadi 173 pasien di tahun 2016, kasus operatif mengalami kenaikan signifikan sebesar 130\% dari 23 kasus di tahun 2015 menjadi 53 kasus di tahun 2016, dan kasus non-operatif mengalami kenaikan sebesar 13,2\% dari 106 kasus menjadi 120 kasus dengan rincian lima kasus terbanyak yang ditangani oleh spesialis bedah plastik adalah luka kronik dengan total 72 kasus mengalami kenaikan $127 \%$ di tahun ke-2, luka bakar dengan total 35 kasus mengalami kenaikan 18,75\% di tahun ke-2, vulnus appertum sebanyak 31 kasus mengalami kenaikan 38,46\% di tahun ke-2, keloid sebanyak 25 kasus mengalami kenaikan 50\% di tahun ke-2, dan basalioma dengan total 23 kasus, mengalami penurunan $35,7 \%$ di tahun ke-2 setelah diadakan penyuluhan. Kasus dan jumlah pasien Bedah Plastik mengalami peningkatan sejak diadakannya layanan Bedah Plastik di RSUD Bangkalan, namun sayangnya pelayanan ini diskontinu di awal tahun 2017. Oleh karena itu sebaiknya diadakan kegiatan wajib kerja dokter spesialis secara berkesinambungan di RSUD Bangkalan Madura, sekaligus 
mendukung Perpres No.04 Tahun 2017 guna membantu efisiensi dan efektivitas masyarakat Madura yang membutuhkan layanan spesialis bedah plastik.

Kata kunci: kasus bedah plastik, Bangkalan, Madura, epidemiologi

\section{PENDAHULUAN}

Madura adalah sebuah pulau yang terletak di timur laut Provinsi Jawa Timur dengan luas $5.168 \mathrm{~km}^{2}$ dan penduduk \pm 4 juta jiwa, yang terdiri dari empat kabupaten, yaitu Bangkalan, Sampang, Pamekasan, dan Sumenep. Bangkalan merupakan kabupaten terbesar di Pulau Madura dan terletak di bagian barat Pulau Madura, dengan Rumah Sakit Syarifah Ambami Rato Ebhu sebagai rumah sakit umum terbesar dan rumah sakit sentra rujukan se-pulau Madura (Wikipedia Ensiklopedia Bebas, 2017). Rumah sakit ini memiliki 25 orang dokter umum orang dan 40 orang dokter spesialis. Namun sayangnya hingga tahun 2015 belum ada dokter spesialis bedah plastik memberikan pelayanan di rumah sakit ini, padahal banyak kasus yang membutuhkan pelayanan spesialis ini (Ebu, 2016).

Sebelum tahun 2015 pelayanan kasus-kasus bedah plastik biasanya ditangani oleh spesialis bedah umum, bahkan mayoritas kasus perawatan luka kronik dirawat oleh perawat-perawat yang sudah mengikuti pelatihan rawat luka yang membuka praktik di kediaman mereka masingmasing, mereka bahkan membuka kursus melatih pemuda setempat dengan pelatihan rawat luka dan kemudian disebar ke seluruh kabupaten di Madura untuk melakukan pelayanan rawat luka dengan metode home care, hal ini tentu berdampak kepada para penderita yang membutuhkan perawatan, di satu sisi mereka terbantu karena tidak perlu repot menyewa transportasi untuk mendapatkan perawatan di rumah sakit, namun di sisi lain banyak kasus infeksi luka dan kejadian luka kronik serta kejadian amputasi meningkat. Ujung-ujungnya jika kasus tersebut tidak bisa tertangani dengan optimal dan tidak membaik atau semakin parah baru segera dirujuk ke rumah sakit terdekat atau ke rumah sakit di Surabaya.

Pada tahun 2015 pertama sekali diadakan pelayanan oleh spesialis bedah plastik di RSUD Syarifah Ambami Rato Ebhu Madura, dua sampai tiga kali seminggu, pelayanan ini berlangsung selama lebih kurang dua tahun, yang hasil evaluasinya akan dilaporkan dalam penelitian retrospektif ini. Selama pelayanan ini berlangsung, ditemukan beberapa kasus-kasus luka kronik yang harus diamputasi karena sudah nekrotik bahkan ada yang sudah menjadi kanker sel skuamous. Rata-rata pasien yang datang dengan kasus-kasus yang sudah end stage tersebut sudah melalui fase perawatan luka selama beberapa bulan dengan metode home care, setelah kehabisan biaya dan belum sembuh juga baru mereka datang ke rumah sakit untuk mendapatkan perawatan lebih lanjut dengan menggunakan BPJS atau asuransi dari pemerintah daerah.

Dari fakta-fakta di atas alangkah lebih baik jika bisa diadakan pelayanan dokter spesialis bedah plastik secara berkesinambungan di RSUD Syarifah Ambami Rato Ebhu Bangkalan agar seluruh kasus bedah plastik yang ada di Pulau Madura dapat ditangani seoptimal dan seefisien mungkin dan dengan diadakannya program wajib kerja dokter spesialis sesuai dengan Perpres No. 04 Tahun 2017 sehingga pasien-pasien yang membutuhkan pelayanan spesialis bedah plastik ini akan terbantu dan tidak perlu jauh-jauh datang ke Surabaya, yang mengharuskan mereka menambah biaya transportasi yang tidak sedikit jumlahnya (Perundang-Undangan, 2017). 


\section{METODE PENELITIAN}

Penelitian ini adalah penelitian deskriptif retrospektif observasional dengan sampel seluruh populasi pasien Bedah Plastik rawat jalan dan rawat inap di RSUD Syarifah Ambami Rato Ebhu Bangkalan dalam kurun waktu 2 tahun, dari tahun 2015 sampai dengan tahun 2016 yang diamati melalui beberapa kategori dan dibandingkan antara tahun 2015 dan 2016 secara kuantitatif.

\section{HASIL PENELITIAN}

Dari data kunjungan pasien rawat jalan dan rawat inap kasus Bedah Plastik ke RSUD Syarifah Ambami Rato Ebhu Bangkalan Madura, tahun 2015 didapatkan ada total 129 pasien baru dengan komposisi 61 pasien laki-laki dan 68 pasien perempuan, di tahun 2016 jumlah pasien baru ini mengalami peningkatan pasien sebanyak 34,1\% menjadi 173 pasien baru di tahun 2016 dengan komposisi 85 pasien lakilaki dan 88 pasien perempuan seperti ditunjukkan pada grafik di bawah ini. Dengan distribusi pasien berdasarkan kategori usia seperti pada Tabel 1.

Tabel 1 Distribusi Pasien Berdasarkan Usia

\begin{tabular}{lcc}
\hline & 2015 & $\mathbf{2 0 1 6}$ \\
\hline$<1$ thn & 5 & 10 \\
$1-10$ thn & 10 & 20 \\
$11-20$ thn & 17 & 18 \\
$21-30$ thn & 18 & 18 \\
$31-40$ thn & 9 & 24 \\
$41-50$ thn & 25 & 40 \\
51-60 thn & 29 & 32 \\
$>60$ thn & 16 & 21 \\
Total & 129 & 173 \\
\hline
\end{tabular}

Dari total jumlah pasien di tahun 2015 terdapat 23 kasus operasi bedah plastik dan
106 kasus perawatan konservatif, kasus operasi bedah plastik mengalami kenaikan signifikan sebesar 130\% menjadi 53 kasus di tahun 2016, dan kasus non-operatif mengalami kenaikan sebesar $13,2 \%$ menjadi 120 kasus.

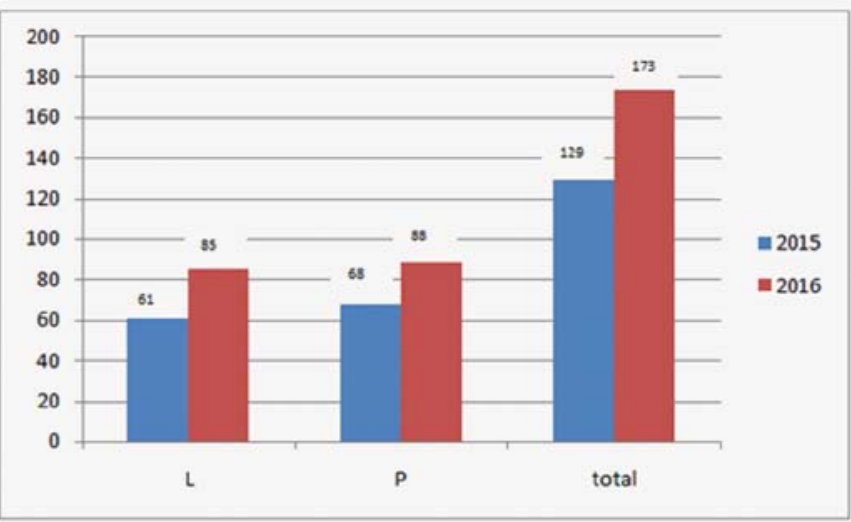

Gambar 1 Distribusi Pasien Berdasarkan Jenis Kelamin

Di tahun pertama kasus operasi bedah plastik tergolong sangat sedikit, hanya 23 kasus operasi dalam 1 tahun, hal ini dikarenakan budaya masyarakat setempat yang menganggap operasi itu hanya untuk pasien-pasien yang sangat gawat dan hampir meninggal, tetapi tidak untuk kasus-kasus elektif, mereka lebih memilih untuk perawatan konservatif atau terapi apapun kecuali operasi, hanya masyarakat yang tinggal di ibukota kabupaten yang mulai berani untuk melakukan operasi dengan keluhan-keluhan elektif seperti soft tissue tumor dan keloid. Setelah tahun kedua tampak peningkatan signifikan kasus operatif sebesar 130\% hal ini kemungkinan besar dikarenakan pasien-pasien yang telah berhasil sembuh dengan baik dengan terapi operatif dilihat oleh masyarakat sekitarnya dan diceritakan ke banyak orang sehingga jumlah konsultasi baru yang datang dan berakhir di meja operasi meningkat. Adapun jumlah kasus terbanyak dalam dua tahun yang meminta pelayanan spesialis bedah plastik di Madura seperti terlihat pada Tabel 2. 
Tabel 2 Distribusi Kasus Pasien Berdasarkan Diagnosis

\begin{tabular}{|c|c|c|c|}
\hline & 2015 & 2016 & Total \\
\hline chronic wound & 22 & 50 & 72 \\
\hline Combustio & 16 & 19 & 35 \\
\hline v.app & 13 & 18 & 31 \\
\hline Stt & 13 & 14 & 27 \\
\hline Keloid & 10 & 15 & 25 \\
\hline basalioma & 15 & 9 & 24 \\
\hline $\operatorname{clp}$ & 4 & 6 & 10 \\
\hline kontraktur & 6 & 3 & 9 \\
\hline sfr.maksilofasial & 5 & 2 & 7 \\
\hline
\end{tabular}

Tampak peningkatan kasus perawatan luka kronik dengan total 22 kasus mengalami kenaikan $127 \%$ di menjadi 50 kasus tahun ke2, luka bakar dengan total 35 kasus mengalami kenaikan $18,75 \%$ di tahun ke-2 dan merupakan kasus cito terbanyak di Madura, vulnus appertum sebanyak 31 kasus mengalami kenaikan 38,46\% di tahun ke-2 tahun, keloid sebanyak 25 kasus mengalami kenaikan 50\% di tahun ke-2, dan basalioma dengan total 23 kasus, mengalami penurunan $35,7 \%$ di tahun ke-2 setelah diadakan

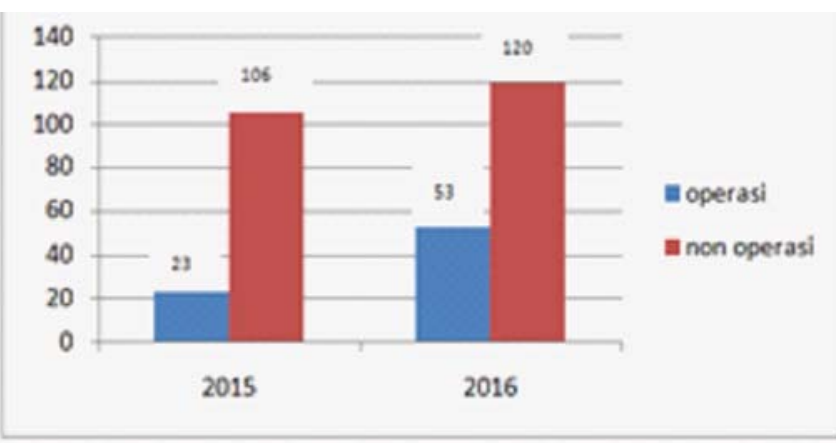

Gambar 3 Distribusi Kasus Pasien Berdasarkan Tipe Kasus

penyuluhan. Menariknya insiden Basalioma di Kabupaten Bangkalan ini tergolong paling tinggi di Indonesia, dengan 2,59/ 100.000 penduduk/ tahun dengan jumlah kasus baru mencapai 15 kasus baru per tahunnya dan jumlah populasi berisiko 927.433 populasi, jika dibandingkan dengan insiden Basalioma di Jakarta 0,285/ 100.000 penduduk/tahunnya dengan jumlah kasus baru 29 kasus per tahunnya dan jumlah populasi berisiko sebanyak 10.177.924 (Regency, 2017; admnfd, 2016). Sementara di RSUD M. Djamil Padang hanya mempunyai 18 kasus baru dalam kurun waktu 5 tahun (Azamris, 2011). Peningkatan kasus perawatan luka kronik dikarenakan banyak kasus-kasus rujukan dari terapi metode homecare yang tidak berhasil yang akhirnya dirujuk ke RSUD dan beberapa di antaranya menjadi kasus operatif, baik itu operasi debridement, amputasi maupun penutupan luka dengan skingraft.

Seluruh pembiayaan pasien bedah plastik dikategorikan menjadi empat kategori, yaitu dengan status pembiayaan pasien umum, BPJS, non-askes, dan sehati.

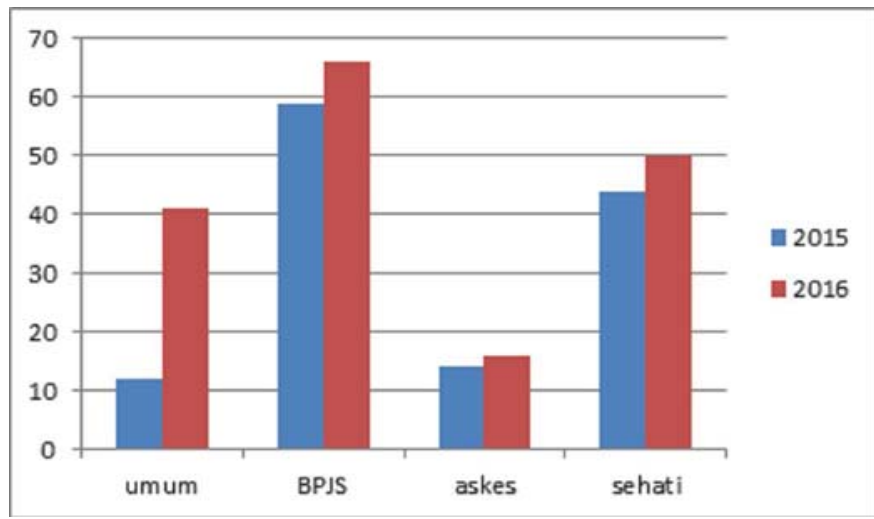

Gambar 4 Distribusi Pasien Berdasarkan Pembiayaan

Tampak kenaikan pasien umum dari 2015 sebanyak 240\% dari 12 pasien menjadi 41 pasien di tahun 2016. Hal ini kemungkinan dikarenakan pasien ingin mendapatkan pelayanan yang cepat dan tidak perlu mengantre di loket BPJS, kemungkinan kedua pasien tidak sempat mengurus BPJS dan asuransi daerah karena kasus cito. 


\section{KESIMPULAN DAN REKOMENDASI}

\section{Kesimpulan}

Berdasarkan fakta di atas, kasus dan jumlah pasien bedah plastik mengalami peningkatan dalam dua tahun sejak diadakannya layanan Bedah Plastik di RSUD Bangkalan. Namun saat ini layanan tersebut ditiadakan karena keterbatasan kemampuan dokter spesialis bedah plastik yang bertugas di sana untuk masuk setiap hari.

\section{Rekomendasi}

Oleh karena itu, sebaiknya diadakan kegiatan wajib kerja dokter spesialis secara berkesinambungan di RSUD Bangkalan Madura oleh dokter-dokter spesialis bedah plastik yang baru lulus, sekaligus mendukung Perpres No. 04 Tahun 2017 guna membantu efisiensi dan efektivitas masyarakat Madura yang membutuhkan layanan spesialis bedah plastik.

\section{DAFTAR PUSTAKA}

Admnfd. 2016. Fakta DKI, Rekam Jejak Ibukota Jakarta, 05 Dec, [Online]. Available: http:/ /faktadki.com/2016/12/05/jumlah-penduduk-dki-jakarta-menurut-usia-tahun-2015/ [May 2017].

Azamris. 2011. 'Kanker Kulit di Bangsal Bedah RS Dr. M. Djamil Padang Januari 2002 Maret 2007', CDK 183 Vol.38 no.2, pp. 109-111.

Ebu, R.S.A.R. 2016. RSA Bangkalan, [Online]. Available: http://rsabangkalan.com/ [Jul 2017].

Perundang-Undangan, S.I.D.J.P. 2017. Peraturan.go.id Kementrian Hukum dan Hak Azasi Manusia Republik Indonesia, [Online]. Available: http://peraturan.go.id/perpres/ nomor-4-tahun-2017.html [Aug 2017].

Regency, B.-S.o.B. (2017) Statistics of Bangkalan, [Online], Available: http://bangkalankab. bps.go.id [May 2017].

Wikipedia Ensiklopedia Bebas. 2017. 14 Jul, [Online], Available: https://id.wikipedia. org/wiki/Pulau_Madura [07 Aug 2017]. 
Medical and Health Science Journal, Vol. 1, No. 2, August 2017 